\title{
TWO NEW SIMILAR SPECIES OF MASDEVALLIA (ORCHIDACEAE: PLEUROTHALLIDINAE) FROM PASCO, PERU
}

\author{
Stig DalströM ${ }^{1,3} \&$ Saul Ruíz Pérez ${ }^{2}$ \\ 12304 Ringling Boulevard, unit 119, Sarasota FL 34237, U.S.A. \\ Lankester Botanical Garden, University of Costa Rica, Cartago, Costa Rica \\ National Biodiversity Centre, Serbithang, Bhutan \\ ${ }^{2}$ Allamanda 142, Surco, Lima 33, Peru \\ ${ }^{3}$ Corresponding author: stigdalstrom@gmail.com
}

\begin{abstract}
Two new species of Masdevallia, subgenus Pygmaeia, section Amaluzae are described, illustrated with line drawings and color photographs, and compared with similar taxa. The two new species are sympatric and share many morphological characteristics, but differ from each other through features such as pubescent sepals versus glabrous sepals, size and coloration. Both new species differ from all other members of the same subgenus and section by much larger plant habits.
\end{abstract}

Key words: New Masdevallia, Pleurothallidinae, Epidendreae, Epidendroideae, Pasco, Peru, taxonomy

In 2006 the genus Masdevallia Ruíz \& Pav., had become massive with over 500 species, classed into numerous subdivisions (Luer, 2000a, 2000b, 2001, 2002, 2003). This vast number of species, in combination with molecular investigations (Abele et. al, 2005; Pridgeon \& Chase, 2001), encouraged Luer to split the genus into 16 new genera, in addition to the remaining Masdevallia (Luer, 2006). The taxonomic advantages of this division of Masdevallia, or improvements of the pre-existing classification by Luer are not recognized by us, however, because of difficulties in separating the various new genera from each other in consistent ways, and in recognizing user-friendly and practical features to readily identify in which genus many species belong. We therefore favor the previous and more conservative taxonomic treatment of the genus as circumscribed by Luer (2000a, 2000b, 2001, 2002, 2003), for scientific, userfriendly and practical reasons. Various authors (e.g. Collantes et al., 2007; Zelenko \& Bermudez, 2009; Zelenko, 2014) also maintain the name Masdevallia as defined by Luer prior to 2006 .

\section{TAXONOMIC TREATMENT}

\section{Masdevallia fenestralis Dalström \& Ruíz-Pérez, sp. nov.}

TYPE: Peru. Huanuco, Choto, along trail Monopampa-
Pozuzo, in dense and seasonally exceedingly wet cloud forest, at ca. $3000 \mathrm{~m}$ elevation, $09^{\circ} 48.249^{\prime} \mathrm{S}$, $075^{\circ} 44.722^{\prime}$ W, 24 Nov. 2013, S. Dalström et al. 3664 (holotype: USM). Figs. 1-3.

Diagnosis. Masdevallia fenestralis appears most closely related to Masdevallia carmenensis Luer \& Malo (Figs.4, 5), in addition to the next described species, which all share a deeply tubular flower. But M. fenestralis differs in the overall much larger size, and with a flower twice as large as M. carmenensis ( $c a$. $10 \mathrm{~cm}$ versus $c a .5 \mathrm{~cm}$ long). Masdevallia fenestralis differs from the following new species by the white and purple, internally pubescent flower, versus an overall smaller sized plant, with a smaller white and glabrous flower.

Epiphytic or terrestrial herb. Plant tall for the subgenus, caespitose. Ramicauls erect, slender, to ca. $6.5 \mathrm{~cm}$ long, enclosed basally by 3 to 4 tubular sheaths. Leaf erect, coriaceous, petiolate, blade basally conduplicate and cuneate, elliptic, obtuse, to $c a$. 17.0 $\times 3.5 \mathrm{~cm}$, including the to $c a .7 \mathrm{~cm}$ long petiole. Inflorescence erect, terete, successive-flowered with at least two flowers, with a to $c a \cdot 12-13 \mathrm{~cm}$ long peduncle and a $c a .2 \mathrm{~cm}$ long rachis; peduncular bracts 2, tubular, below the middle of the peduncle, $c a .0 .5$ cm long; floral bracts appressed, tubular, ca. 1.0-1.5 $\mathrm{cm}$ long; pedicel to $c a .1 .5 \mathrm{~cm}$ long; ovary sulcate, 


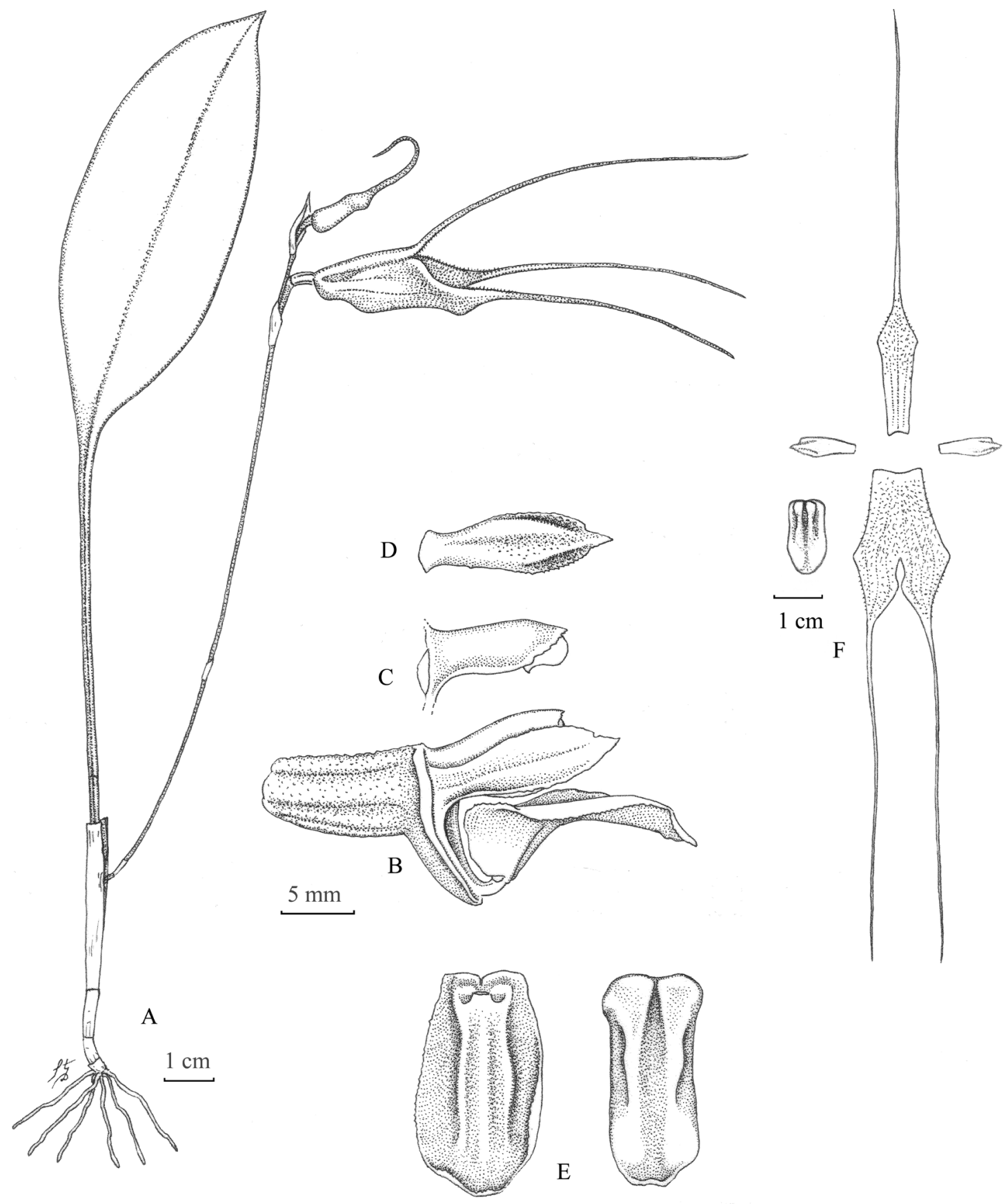

FIgure 1. Masdevallia fenestralis. A. Plant habit. B. Ovary, petal, column and lip, lateral view. C. Column, lateral view. D. Petal, internal lateral view. E. Lip, ventral (slightly flattened) and dorsal views. F. Dissected flower. Drawn from holotype by Stig Dalström. 


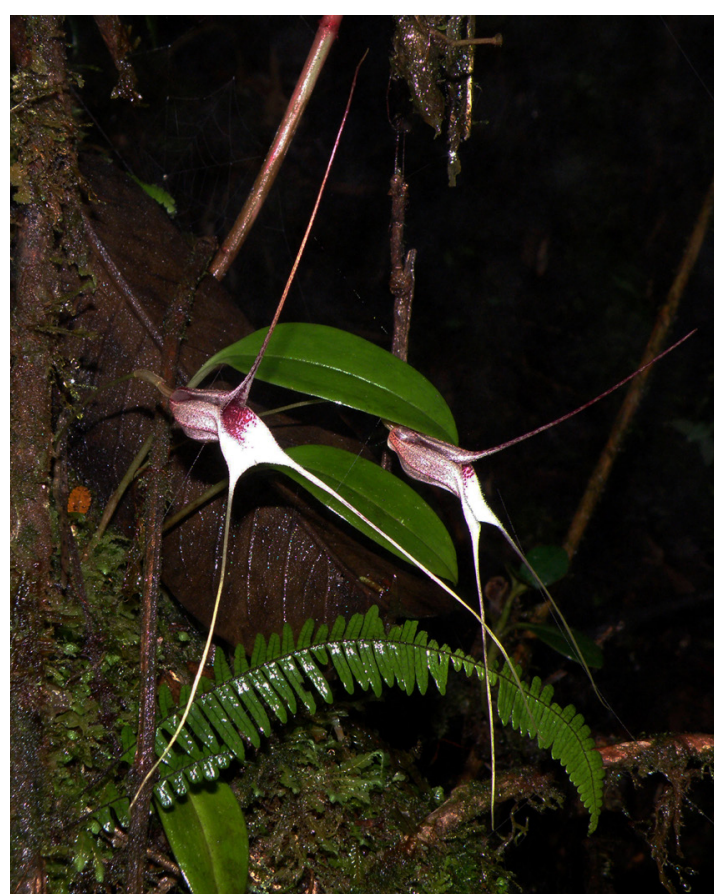

Figure 2. Masdevallia fenestralis in situ. Photo by S. Dalström.

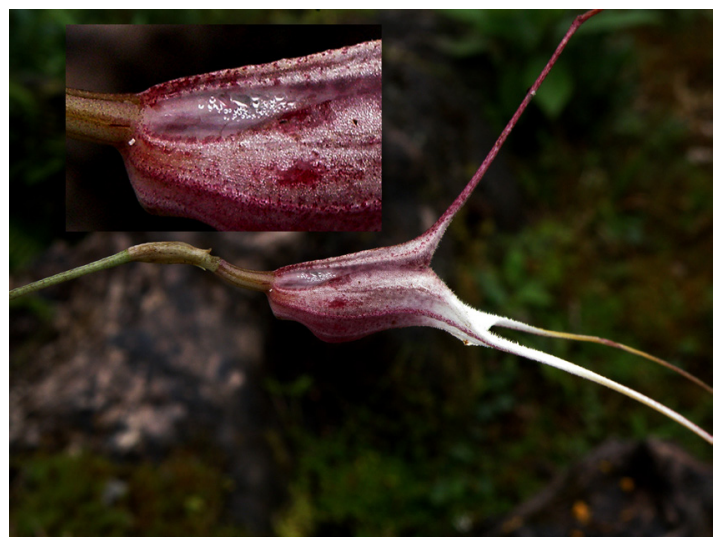

Figure 3. Masdevallia fenestralis flower. Photo by S. Dalström.

smooth to weakly rugose, $c a$. $0.5-1.0 \mathrm{~cm}$ long. Flower tubular, forming a ca. $20 \mathrm{~mm}$ long sepaline tube with a ca. 8-9 mm long and ca. 1.5-2.0 mm broad obliquely ovate, transparent section (a 'window') near the base and along the seam between the sepals; dorsal sepal white with deep purple spots, mottling and longitudinal stripes along the 3 veins, microscopically pubescent and carinate externally, densely pubescent internally, cuneate to linear, angulate-obovate and

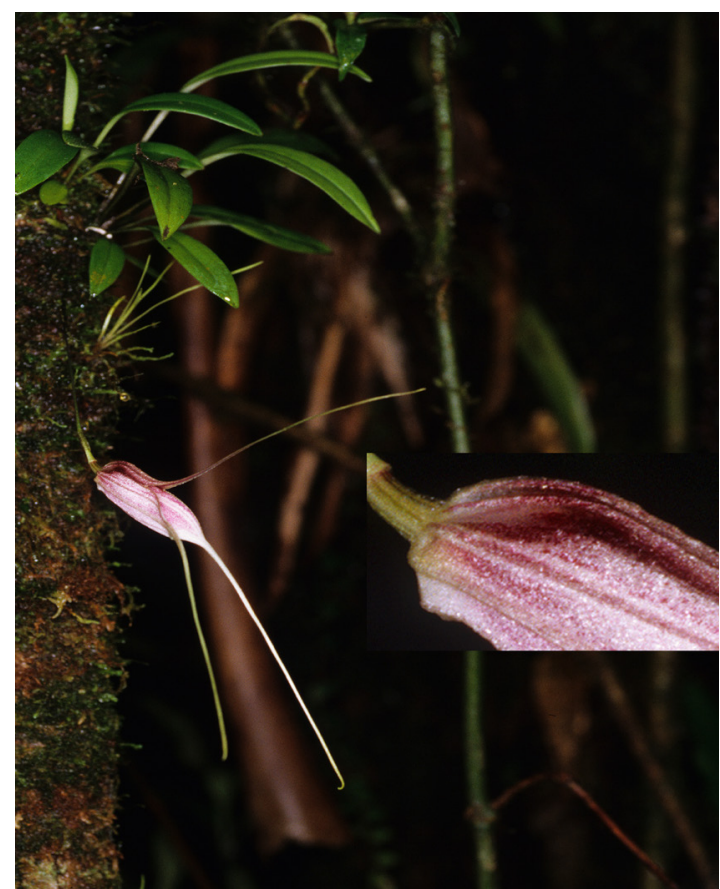

Figure 4. Masdevallia carmenensis in situ, Chiguinda road, Ecuador. Photo by S. Dalström.

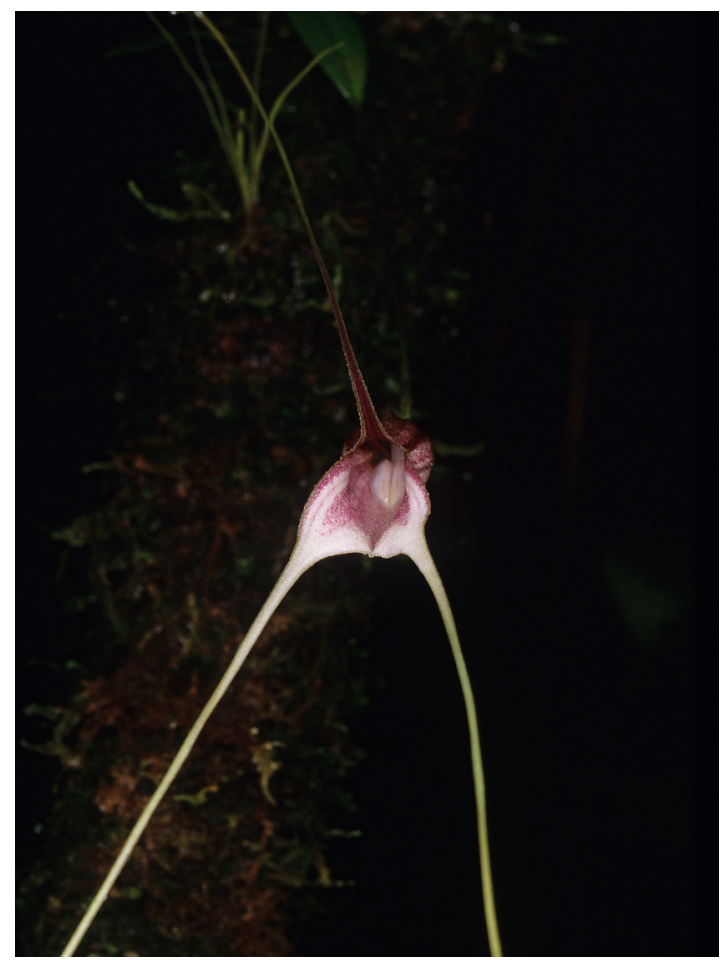

FIgURE 5. Masdevallia carmenensis flower. Photo by S. Dalström.

LANKESTERIANA 15(1), April 2015. (C) Universidad de Costa Rica, 2015. 
connate to the lateral sepals for $c a .20 \mathrm{~mm}$, acuminate into a thin more or less erect to arching purple tail, ca. $90 \times 10 \mathrm{~mm}$, including the $c a .60 \mathrm{~mm}$ long tail; lateral sepals similar in texture and coloration, microscopically pubescent and carinate externally, and densely pubescent internally, connate for $c a .20 \mathrm{~mm}$, obliquely and angulate-ovate, acuminate with apical whitish tails, $c a .105 \times 22 \mathrm{~mm}$ combined, including the $c a .75 \mathrm{~mm}$ long tails; petals white with a purple stripe, cartilaginous, oblong, obtuse with an elongate acute apex and slightly serrate, with a longitudinal fleshy ridge, extending from the slightly unguiculate base, continuing along the midline and ending with the narrowly acute apex, $c a .13 .5 \times 4.3 \mathrm{~mm}$; lip basally white and with a pink lamina, hinged on the column foot, with a basal, dorsally furrowed truncate swelling, and weakly erect lateral lobes that turn slightly downwards near and above the middle, basally truncate, then slightly obovate when flattened, with a weakly revolute apex, $c a .16 \times 10 \mathrm{~mm}$ when flattened; column white with purple lateral stripes, straight, $c a$. $10 \mathrm{~mm}$ long, with an equally long, curved foot; anther cap white and campanulate; pollinia not seen.

Additional material seen: Peru. Only a small population of plants was discovered in the same location as the holotype. No other collections known.

Distribution: Masdevallia fenestralis has only been found in a single location, along the trail between Monopampa and Pozuzo, at ca. $3000 \mathrm{~m}$.

ETYmology: This species is named in reference to the window-like patch of translucent tissue near the base on each side of the sepaline tube (fenestralis; Latin for windowed).

Masdevallia fenestrellata Dalström \& Ruíz-Pérez, sp. nov.

TYPE: Peru. Huanuco, Choto, along trail MonopampaPozuzo, in dense and seasonally exceedingly wet cloud forest, at $c a .3000 \mathrm{~m}$ elevation, $09^{\circ} 48.249^{\prime} \mathrm{S}$, 07544.722’W, 24 Nov. 2013, S. Dalström et al. 3663 (holotype: USM). Figs. 6-8.

Diagnosis. Masdevallia fenestrellata is morphologically similar and appears closely related to the much larger Masdevallia fenestralis but differs in an overall smaller size and a white, internally glabrous flower. It also appears closely related to Masdevallia carmenensis, but differs in a larger vegetative size and having a white flower, versus white with purple stripes for the latter species.

Epiphytic or terrestrial herb. Plant medium sized for the genus, caespitose. Ramicauls erect, slender, to $c a .4 \mathrm{~cm}$ long, enclosed basally by 3 to 4 tubular sheaths. Leaf erect, coriaceous, petiolate, blade basally conduplicate and cuneate, elliptic, obtuse, to $c a .10 .0 \times 2.5 \mathrm{~cm}$, including the $c a .3 \mathrm{~cm}$ long petiole. Inflorescence erect, terete, successiveflowered with at least two flowers, with a to $c a$. $8 \mathrm{~cm}$ long peduncle and a $c a .2 \mathrm{~cm}$ long rachis; peduncular bracts 2 , tubular, below the middle of the peduncle, ca. $0.5-0.7 \mathrm{~cm}$ long; floral bracts appressed, tubular, $c a \cdot 1.0-1.2 \mathrm{~cm}$ long; pedicel to $c a$. $1 \mathrm{~cm}$ long; ovary sulcate, weakly rugose, $c a$. 0.6$0.7 \mathrm{~cm}$ long. Flower tubular, forming a $c a .18 \mathrm{~mm}$ long sepaline tube, with a $c a .5 \mathrm{~mm}$ long and $c a$. $1 \mathrm{~mm}$ broad obliquely ovate, transparent section (a 'window') near the base and along the seam between the sepals; dorsal sepal dull white, glabrous and carinate externally, glabrous internally, cuneate to linear, angulate-obovate and connate to the lateral sepals for $c a .18 \mathrm{~mm}$, acuminate into a thin suberect to arching whitish to pale yellow tail, $c a .70 .0 \times 0.8$ $\mathrm{mm}$, including the $c a .45 \mathrm{~mm}$ long tail; lateral sepals similar in texture and coloration but with some pale yellow basally, glabrous and carinate externally, and glabrous internally, connate for $c a .20 \mathrm{~mm}$, obliquely and angulate-ovate, acuminate with apical pale yellowish tails, $c a .70 \times 17 \mathrm{~mm}$ combined, including the ca. $45 \mathrm{~mm}$ long tails; petals white, cartilaginous and slightly oblique, weakly unguiculate, oblong, obtuse with a shortly acuminate, narrowly acute apex and slightly verrucose and serrate on the dorsal half side, with a longitudinal fleshy ridge, extending from the base, continuing along the midline and ending with the narrowly acute apex, ca. $8 \times 2$ $\mathrm{mm}$; lip white, hinged on the column foot, with a basal, dorsally shallow furrowed truncate swelling, and strongly revolute edges of the lamina, forming a slightly bilobed apex, which is obtuse to rounded when the lip is flattened, $c a .9-10 \times 6 \mathrm{~mm}$ when flattened; column white, straight, ca. $6 \mathrm{~mm}$ long, with an equally long, curved foot; anther cap white and campanulate; pollinia not seen. 


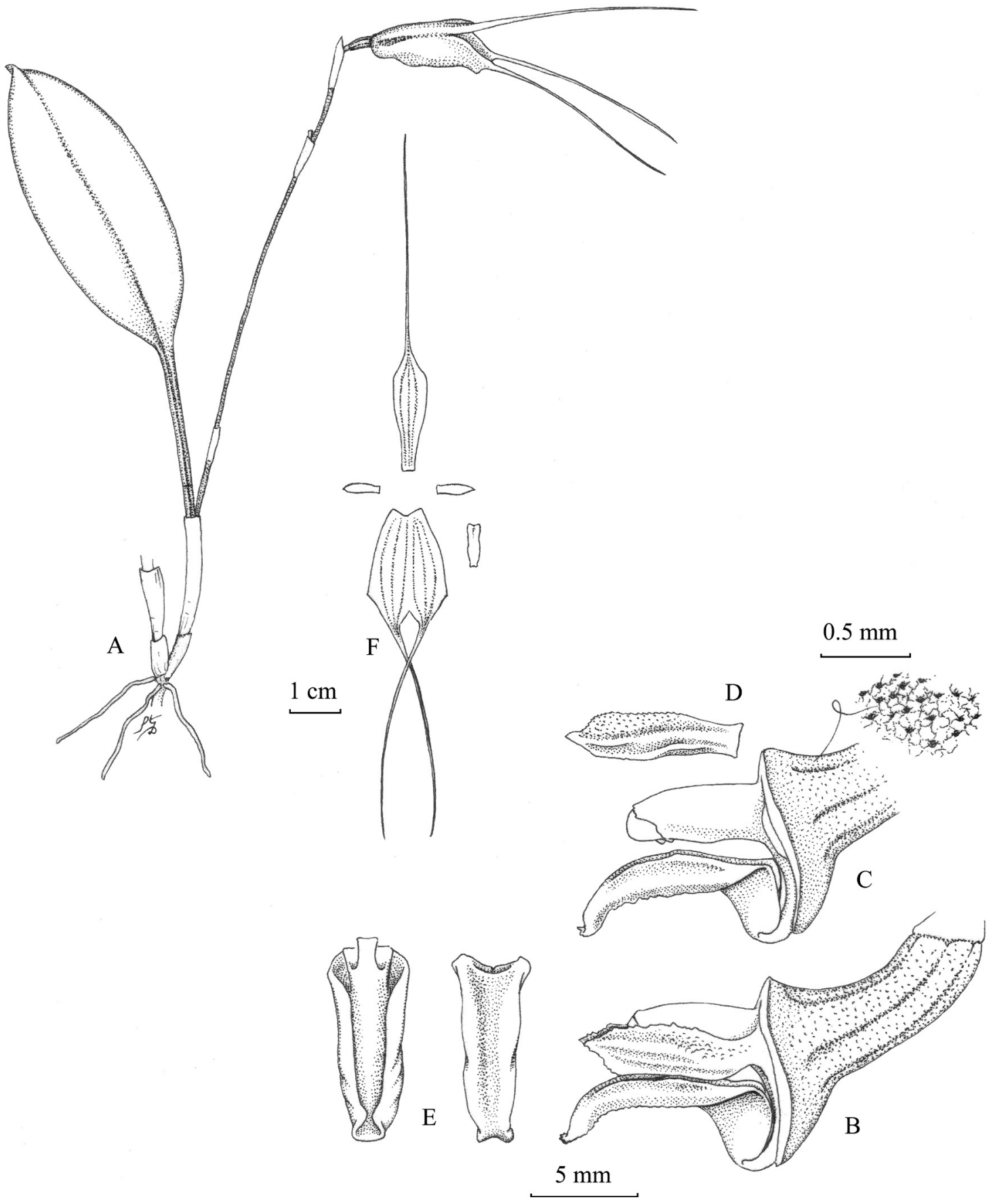

Figure 6. Masdevallia fenestrellata. A. Plant habit. B. Ovary, petal, column and lip, lateral view. C. Column and lip, lateral view. D. Petal, internal lateral view. E. Lip, ventral and dorsal views. F. Dissected flower. Drawn from holotype by Stig Dalström. 


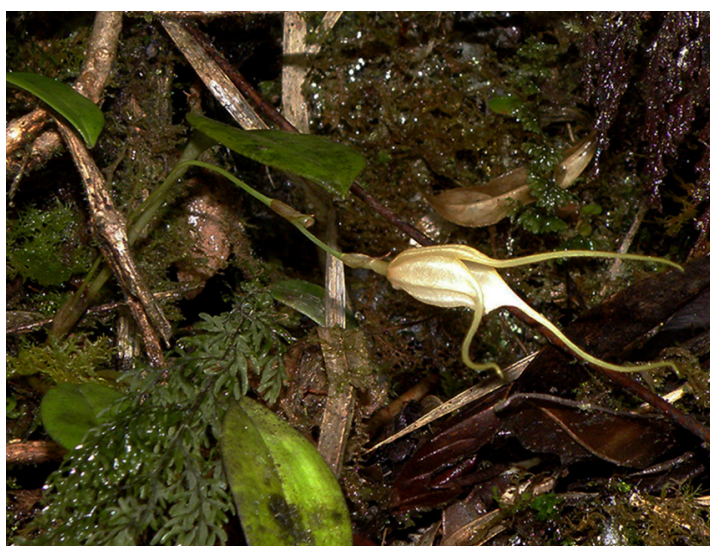

Figure 7. Masdevallia fenestrellata in situ. Photo by S. Dalström.

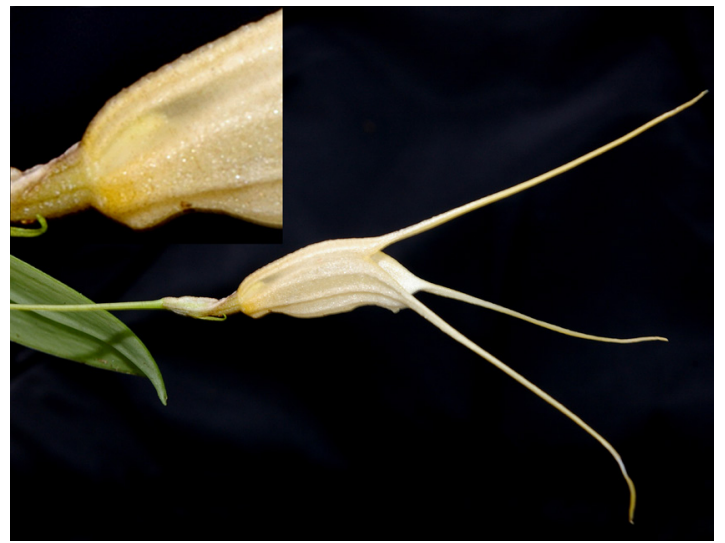

Figure 8. Masdevallia fenestrellata flower. Photo by S. Ruíz Pérez.

Additional material seen: Peru. Only a small population of plants was discovered in the same location as the holotype. No other collections known.

Distribution: Masdevallia fenestrellata has only been found in a single location, along the trail between Monopampa and Pozuzo, at ca. $3000 \mathrm{~m}$ where it grows sympatrically with the larger Masdevallia fenestralis.

Etymology: This species is named in reference to the small 'window-like' patch of translucent tissue near the base on each side of the sepaline tube (fenestrellata; Latin for "with a small window").

Masdevallia fenestrellata and the much showier Masdevallia fenestralis were originally discovered several years ago by Saúl Ruíz Pérez in some extremely wet and dense cloud forest along the trail between Monopampa in Huanuco, and Pozuzu in Pasco (Figs.

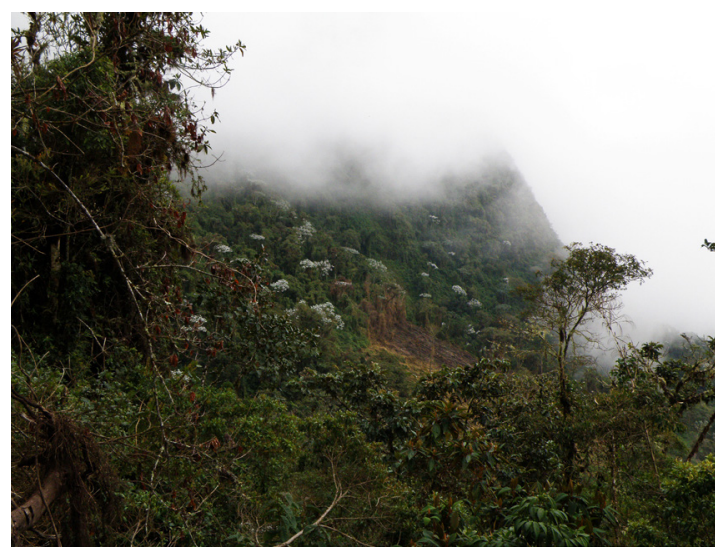

FIgURE 9. Masdevallia habitat along the MonopampaPozuzu trail. Photo by S. Dalström.

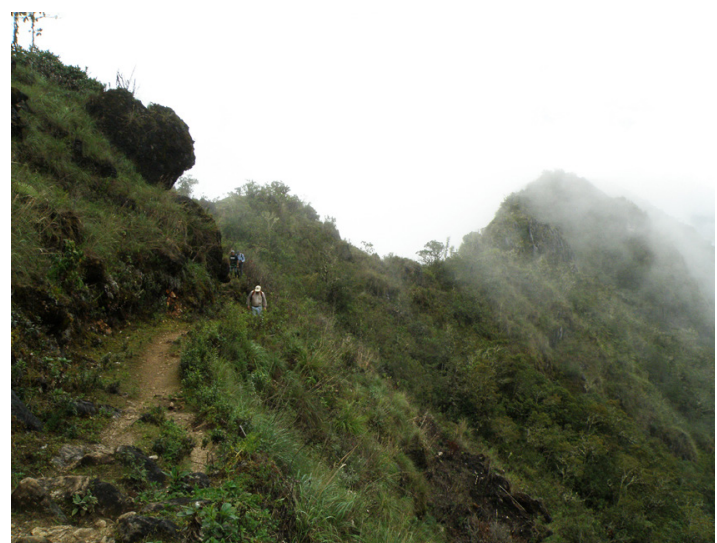

Figure 10. The Monopampa-Pozuzu trail. Photo by S. Dalström.

$9,10)$. Both species grow intermingled with each other and flower simultaneously but no intermediate forms have been observed. The only known collection site is an almost constantly rainy, thick and impenetrable cloud forest at rather high altitude in central Peru. Uncountable wanderers have used the ancient trail that crosses the summit of Abra de Vacas, but hardly any orchid explorers, which promises to reveal more interesting taxa over time. The collection site was revisited by the two authors in 2013 after a strenuous hike which included several high-risk passages of variously entertaining sorts.

ACKNOWLEDGMENTS. We thank the staff at the Instituto Recursos Naturales (INRENA), and Betty Millán and Ricardo Fernández at the Universidad de San Marcos, Museo de Historia Natural, Lima, for providing permits and assistance. We also thank Wesley Higgins for commenting 
on the manuscript, Manolo Arias Silva and his family and staff of Perúflora for logistic support and hospitality, and Steven Beckendorf, Guido Deburghgraeve, Jan Sönnemark and Moises Ruíz Pérez for stimulating company in the field.

\section{LiTERATURE CITED}

Abele, C., Rudolph, B., Thiede, J. \& Rohwer, J. G. (2005). Phylogeny of the genus Masdevallia Ruíz \& Pav., based on morphological an molecular data. Proceedings of the $18^{\text {th }}$ World Orchid Conference, Dijon, France, 111-115.

Collantes M. B., Soto, C. \& Koechlin, J. (2007). Orchids in Inkaterra at Machu Picchu pueblo hotel. Inkaterra Asociación. Andalucia 174, Miraflores, Lima 18, Peru.

Luer, C. A. (1986). Icones Pleurothallidinarum 2, Systematics of Masdevallia (Orchidaceae). Monogr. Syst. Bot. Missouri Bot. Gard., 16.

Luer, C. A. (2000a). Icones Pleurothallidinarum 19. Systematics of Masdevallia part one. Monogr. Syst. Bot. Missouri Bot. Gard., 77, 1-264.
Luer, C. A. (2000b). Icones Pleurothallidinarum 21. Systematics of Masdevallia part two. Monogr. Syst. Bot. Missouri Bot. Gard., 82, 265-518.

Luer, C. A. (2001). Icones Pleurothallidinarum 22. Systematics of Masdevallia part three. Monogr. Syst. Bot. Missouri Bot. Gard., 86, 510-780.

Luer, C. A. (2002). Icones Pleurothallidinarum 23. Systematics of Masdevallia part four. Monogr. Syst. Bot. Missouri Bot. Gard., 87, 781-1047.

Luer, C. A. (2003). Icones Pleurothallidinarum 25. Systematics of Masdevallia part five. Monogr. Syst. Bot. Missouri Bot. Gard., 91, 1049-1293.

Luer, C. A. (2006). Icones Pleurothallidinarum 28. A reconsideration of Masdevallia, Systematics of Specklinia and vegetatively similar taxa (Orchidaceae). Monogr. Syst. Bot. Missouri Bot. Gard., 105.

Pridgeon, A. M. \& Chase, M. W. (2001). A phylogenetic reclassification of Pleurothallidinae. Lindleyana, 16(4), 235-271.

Zelenko, H. (2014). Orchids, Masdevallia with its segregates including Dracula. ZAI Publications, Quito, Ecuador

Zelenko, H. \& Bermudez, P. (2009). Orchids, species of Peru. ZAI Publications, Quito, Ecuador. 